\title{
Family medicine's obligation to society
}

$\mathrm{F}$ amily physicians must become more accountable to society, says newly elected President of the College of Family Physicians of Canada Dr. Sandy Buchman.

"I believe that medicine in general, and family medicine in particular, should begin to honour what I view as the social obligation or contract that medicine has with society," says Buchman. "We have to be able to meet the needs of Canadians."

That onus should translate into such things as physician involvement in finding ways for vulnerable populations, such as those in the Aboriginal community and those living in poverty, to get readier access to the health care system, Buchman indicated in a Nov. 4 interview following the college's annual general meeting in Montréal, Quebec.

"These Canadians don't get the same access to health care," he says. "We can't control certain catastrophes. We can't control politics. But we can target the social determinants of health."

It begins with further incorporating social justice issues into medical education, from the undergraduate level on through continuing medical education, says Buchman.

"I'd also like to see the development of a think-tank or symposium on social accountability issues and the establishment of a social accountability committee," says Buchman. "It needs to build momentum. We need to get the wisdom of our members across the country."

Delegates to Family Medicine Forum 2011 were also told that the college wants to ensure that physicians who focus their practices in such areas as palliative care, mental health and emergency medicine are kept within the rubric of the college's umbrella.

To that end, the college's annual report highlights the "Section of Family Physicians with Special Interests or Focused Practices," aimed at helping physicians with similar interests to network and enhance their professional development (www.cfpc.ca/uploaded

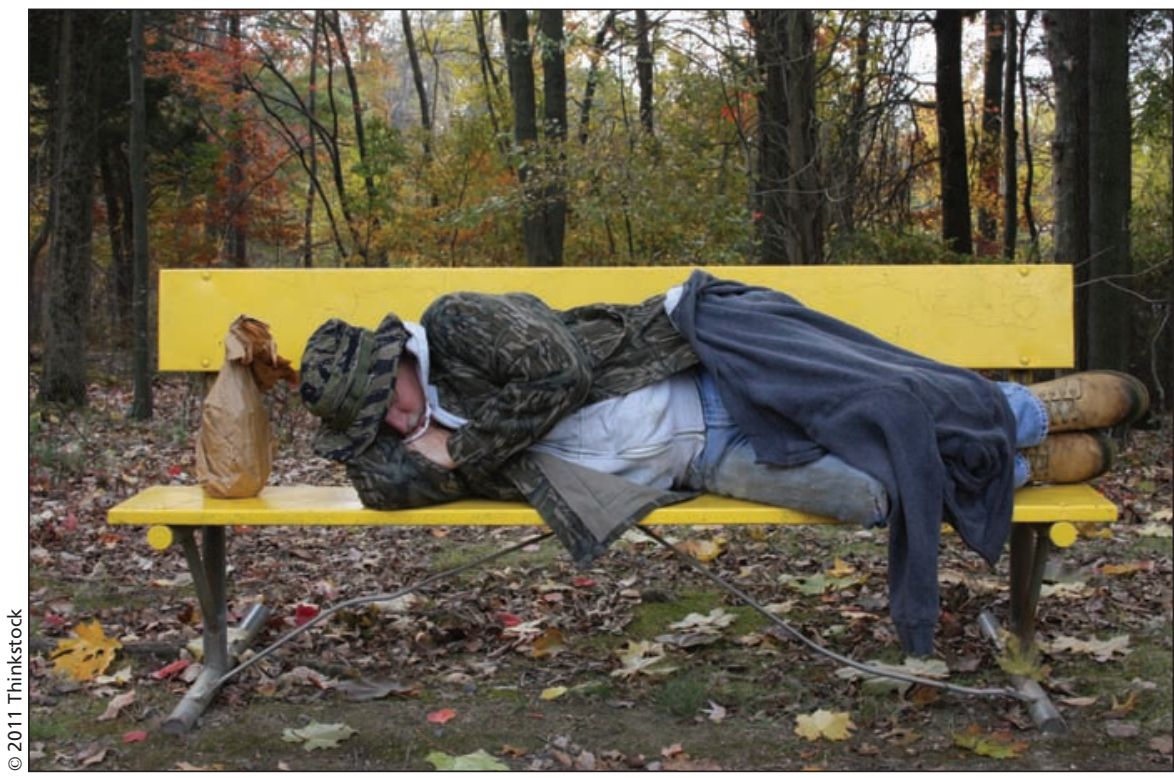

Medicine, and particularly family medicine, has a social obligation to meet the needs of all Canadians, including the most vulnerable and marginalized, says newly elected President of the College of Family Physicians of Canada Dr. Sandy Buchman.

Files/Publications/_PDFs/AnnualReport _EN\%202011_FINAL.pdf).

Concerns have been raised that the trend toward family physicians adopting focused practices will lead to diminished access to comprehensive care (www.cmaj.ca/lookup/doi/10 .1503/cmaj.109-4036) Some critics are also concerned that family physicians may not have adequate training for focused practices but advocates say the trend will increase the overall skill set of family doctors and provide patients with access to a wider range of services, particularly in team-based settings (www.cmaj.ca/lookup/doi/10 .1503/cmaj.109-4040).

No matter the effect, doctors with special interests still need a home within the college, and the new section provides one, says Dr. Cal Gutkin, the college's CEO and executive director.

The college's focused-practice section is "still fairly new, and it's not fully understood even by some of [our] own people from across the country, but it is just addressing another reality," Gutkin says.

The annual report indicates that the college is developing new programs for focused practices in areas such as global health and occupational medicine. Each program within the section is eligible to create "enhanced skills residency training" and practice-based pathways leading to "recognition of family physicians with added competencies."

The annual report also indicates that the college is revamping medical education programs so that they focus on what it calls a "Triple C Competencybased Curriculum " - that is, one based on comprehensive care; continuing education and patient care; and centred in family medicine.

"That is a major initiative, shifting the focus of family medicine in residency training from being totally timebased to one that is based on achieving competencies, and defining those competencies more clearly for learners and for faculty," Gutkin says.

Gutkin adds that the college is also pleased by the trend of more medical students opting to go into family medicine. "One of the most exiting things that happened this year and over the past few years is the increase 
in popularity of family medicine as a career choice among graduating medical students."

The report also makes note of the college's position paper on improving patient access to medical services, $A$ Vision for Canada: Family Practice The Patient's Medical Home (www .cfpc.ca/A_Vision_for_Canada). The vision is based on every patient at a family practice having access not only to a personal family physician, but also to other health care professionals, either on-site, in the community or via virtual connections.

"Wherever I go and whoever I talk to, the issue is access - access to family physicians, access to health care services at all levels. That's really what troubles Canadians the most," says Dr. Rob Boulay, the college's outgoing president. "We recognize that working with other health care professionals really helps patients get everything they need."
The annual report also sets out the college's three main objectives over the forthcoming year: to champion quality health care for all people in Canada; to support members through formative and life-long education, research, and the promotion of best practices; and to ensure that the role of the family physician is well-understood and highly valued. — Roger Collier, CMAJ

CMAJ 2011. DOI:10.1503/cmaj.109-4049 